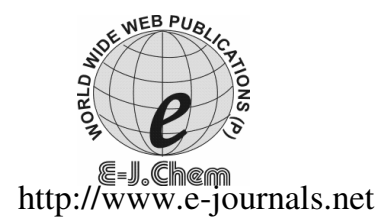

ISSN: 0973-4945; CODEN ECJHAO

E-Journal of Chemistry

2010, 7(4), 1391-1395

\title{
Complexation and Antimicrobial Studies of Some Divalent Metal Chelates
}

\author{
SUPARNA GHOSH* ${ }^{*}$ and SUMAN MALIK \\ Department of Chemistry, \\ S.V. College, Bairagarh, Bhopal-462030, India. \\ suparnabpl@yahoo.co.in
}

Received 4 November 2009; Accepted 1 December 2009

\begin{abstract}
Metal chelates of $\mathrm{Ni}(\mathrm{II})$ and $\mathrm{Cu}$ (II) with the ligand 5-acetamido1,3,4-thiadiazole-2-sulphonamide have been synthesized. The isolated compounds have been characterized by elemental analysis, molar conductivity, magnetic moment, electronic and IR spectral studies. The analytical data reflects the metal to ligand stoichiometry to be $1: 2$. The conductivity data of the complexes also suggests their non-electrolytic nature. The stability constants and free energy change for the complexes have been calculated.. Ligand and their complexes have been screened for their biological activity and the data show good activity of these complexes and ligands.
\end{abstract}

Keywords: Schiff base, Conductivity, Stoichiometry, Non-electrolytic, Stability constant.

\section{Introduction}

Schiff base metal chelates are widely applicable because of their industrial and biological importance and hence have well been studied in the past ${ }^{1,2}$. A detailed survey of literature reveals that very little work has been done on metal complexes of diuretic drugs. Nickel and copper salts have been reported to have therapeutic value $e^{3-5}$. Therefore, in the present communication, synthesis and characterization of metal complexes of $\mathrm{Ni}(\mathrm{II})$ and $\mathrm{Cu}$ (II) with 5-acetamido -1,3,4 - thiadiazole - 2 - sulphonamide (acetazolamide) has been done.

\section{Experimental}

All the chemicals used were of AR/GR grade. Pure sample of acetazolamide (AZM), molecular formula $\mathrm{C}_{4} \mathrm{H}_{6} \mathrm{~N}_{4} \mathrm{O}_{3} \mathrm{~S}_{2}$, molecular weight 222.24, was obtained from Shalak's Pharmaceuticals. Metal salts $\mathrm{NiCl}_{2}$ and $\mathrm{CuCl}_{2}$ used were of Merck. Solvents used were methanol, acetone and deionized double distilled water. 


\section{Preparation of Schiff base}

Equimolar solutions of pure drug and salicyladehyde were separately dissolved in methanol-water mixture (1:1) and refluxed for four hours and kept for a day. Pale yellow crystals of acetazolamide Schiff base were formed in the reaction mixture which were filtered and washed thoroughly with 50\% methanol, dried over vacuum and weighed. Melting point of Schiff base was recorded.<smiles></smiles>

Figure 1. Structure of Schiff base.

\section{Synthesis of complex}

For the synthesis of complex, ligand-metal ratio was confirmed by conductometric titrations using monovariation method on Systronics conductivity meter using dip type electrode. Conductometric titrations supported 2:1 (L:M) ratio in the complex which was further supported by Job's method ${ }^{6}$ of continuous variation as modified by Turner \& Anderson ${ }^{7}$.The stability constants and free energy change values were also calculated.

For the synthesis of complex of AZM-SA-Ni and AZM-SA-Cu, $0.006 \mathrm{M}$ ligand solution (AZM- SA) was prepared in 60\% acetone and refluxed for four hours with $0.003 \mathrm{M}$ solution of $\mathrm{NiCl}_{2}$ and $\mathrm{CoCl}_{2}$ separately. The refluxed solutions were kept for some days. Solid crystalline compounds appeared in the solution, which were filtered, washed with $60 \%$ acetone, dried and weighed, Melting point of the complexes were recorded.

\section{Analytical procedure}

The magnetic moments were obtained by vibrating sample magnetometer (model 7304 Lakeshore with a 735 Controller and 450 Gauss meter). Elemental analysis were carried out on model 240 Perkin elemental analyzer. Metal contents were determined gravimetrically. The electronic spectra of the metal complexes in DMF were recorded on JASCO 7800 Elico SL-159 and Shimadzu UV-160A UV-VIS spectrophotometers. The infrared spectra were measured on a Nicolet 400 D FT- IR spectrophotometer in $\mathrm{KBr}$ pellets. The melting points of the ligand and complexes were recorded in open capillaries on a capillary melting point apparatus.

\section{Antibacterial activity}

Above synthesized compounds and the ligand (Schiff base) were screened against bacteria Escherichia coli by filter paper disc method at various concentrations using nutrient agar as medium. Sterilized filter papers of $5 \mathrm{~mm}$ diameter were soaked in solutions of different concentrations of test samples and introduced on nutrient agar plates. These plates were incubated for $48 \mathrm{~h}$ at $35^{\circ} \mathrm{C}$.

\section{Results and Discussion}

On the basis of physicochemical characteristics (Table 1) it has been found that both the complexes are non- hygroscopic, stable at room temperature, insoluble in water but fairly soluble in DMSO. The magnetic moment data indicate that $\mathrm{Ni}(\mathrm{II})$ and the $\mathrm{Cu}(\mathrm{II})$ complexes to be paramagnetic in nature. The molar conductance values for both the complexes were found between 10-17 $\Omega^{-1} \mathrm{~cm}^{2} \mathrm{~mol}^{-1}$ in DMSO, which indicate their non-electrolytic nature. Elemental analysis data, formula weights and melting points are given in Table 2. 
Table 1. Synthesis and physicochemical characteristics of complexes

\begin{tabular}{|c|c|c|c|c|c|c|c|}
\hline & $\begin{array}{l}\text { Ligand- } \\
\text { Metal ratio }\end{array}$ & Colour & $\begin{array}{c}\text { Yield, } \\
\%\end{array}$ & $\begin{array}{c}\text { Stability } \\
\text { constant log K, } \\
\text { L/mole }\end{array}$ & $\begin{array}{c}\Delta \mathrm{F} \\
\mathrm{K} \mathrm{cal} / \mathrm{mole}\end{array}$ & $\begin{array}{c}\text { Molar } \\
\text { Conductance } \\
\Omega^{-1} \mathrm{~cm}^{2} \mathrm{~mol}^{-1}\end{array}$ & $\begin{array}{l}\mu_{\text {eff }} \\
(\mathrm{BM})\end{array}$ \\
\hline AZM-SA & - & $\begin{array}{l}\text { Pale } \\
\text { yellow }\end{array}$ & 54.5 & 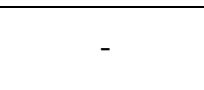 & - & 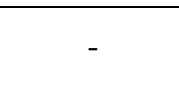 & - \\
\hline$(\mathrm{AZM})_{2} \mathrm{Ni}$ & $2: 1$ & $\begin{array}{l}\text { Pale } \\
\text { Green }\end{array}$ & 65 & 10.84 & -15.580 & 13.0 & 3.18 \\
\hline$(\mathrm{AZM})_{2} \mathrm{Cu}$ & $2: 1$ & $\begin{array}{l}\text { Dark } \\
\text { Green }\end{array}$ & 42.5 & 12.08 & -17.056 & 14.6 & 1.83 \\
\hline
\end{tabular}

Table 2. Analytical data of complexes

\begin{tabular}{|c|c|c|c|c|c|c|}
\hline \multirow{2}{*}{ Complex } & \multicolumn{5}{|c|}{ Elemental analysis \% found (calculated) } & \multirow{2}{*}{$\begin{array}{l}\text { Melting } \\
\text { point, }{ }^{\circ} \mathrm{C}\end{array}$} \\
\hline & $\mathrm{C}$ & $\mathrm{H}$ & $\mathrm{N}$ & S & Metal & \\
\hline$\left(\mathrm{C}_{11} \mathrm{H}_{9} \mathrm{~N}_{4} \mathrm{O}_{4} \mathrm{~S}_{2}\right)_{2} \mathrm{Ni}$ & $\begin{array}{c}35.00 \\
(35.45)\end{array}$ & $\begin{array}{c}2.80 \\
(2.41)\end{array}$ & $\begin{array}{c}14.93 \\
(15.03)\end{array}$ & $\begin{array}{c}17.14 \\
(17.18)\end{array}$ & $\begin{array}{c}7.96 \\
(7.91)\end{array}$ & 260 \\
\hline$\left(\mathrm{C}_{11} \mathrm{H}_{9} \mathrm{~N}_{4} \mathrm{O}_{4} \mathrm{~S}_{2}\right)_{2} \mathrm{Cu}$ & $\begin{array}{c}36.98 \\
(36.00) \\
\end{array}$ & $\begin{array}{c}2.50 \\
(2.91) \\
\end{array}$ & $\begin{array}{c}15.69 \\
(16.67) \\
\end{array}$ & $\begin{array}{r}17.93 \\
(17.50) \\
\end{array}$ & $\begin{array}{r}8.86 \\
(8.91) \\
\end{array}$ & 199 \\
\hline
\end{tabular}

\section{Electronic spectra}

The electronic spectra provide the detailed information about the electronic structure of the metal complexes. The electronic spectra of the complexes were recorded in solution state. The energies of the observed spin allowed bands in both the complexes agree with the octahedral geometry The electronic spectrum of the $\mathrm{Ni}$ (II) complex displays three bands at $12500 \mathrm{~cm}^{-1}, 18900 \mathrm{~cm}^{-1}$ and $26400 \mathrm{~cm}^{-1}$ assigned due to ${ }^{3} \mathrm{~A}_{2 \mathrm{~g}}(\mathrm{~F}) \rightarrow{ }^{3} \mathrm{~T}_{2 \mathrm{~g}}(\mathrm{~F}),{ }^{3} \mathrm{~T}_{1 \mathrm{~g}}(\mathrm{~F})$ and $3 \mathrm{~T}_{1 \mathrm{~g}}(\mathrm{P})$ transitions respectively, which indicate octahedral geometry ${ }^{8}$ of $\mathrm{Ni}(\mathrm{II})$ complex which is also supported by the $\mu_{\text {eff }}$ value $^{9}$ (3.18 B.M.). The electonic spectra of $\mathrm{Cu}$ (II) complex shows two ligand field bands at $13700 \mathrm{~cm}^{-1}$ and $18000 \mathrm{~cm}^{-1}$ assigned to the transitions ${ }^{2} \mathrm{Eg} \rightarrow{ }^{2} \mathrm{~T}_{2 \mathrm{~g}}$ and charge transfer band respectively. The electronic spectra of $\mathrm{Cu}$ (II) complex suggests an octahedral geometry ${ }^{10}$, which is further supported by the $\mu$ eff, value $^{9}$ (1.83 B.M.).

\section{Infrared spectra}

The IR spectra ${ }^{11,12}$ of Schiff base shows a sharp band near $1680 \mathrm{~cm}^{-1}$ which may be due to azomethine linkage and shows lowering in frequency in metal complexes indicating the coordination of metal ions through azomethine linkage. Strong bands observed at $1580 \mathrm{~cm}^{-1}$ and $1590 \mathrm{~cm}^{-1}$ indicate the presence of $(\mathrm{CH}=\mathrm{N})$ bonds in complexes. Bands observed at $1176 \mathrm{~cm}^{-1}, 1175 \mathrm{~cm}^{-1}$ and $1173.5 \mathrm{~cm}^{-1}$ are characteristics of $\mathrm{SO}_{2}-\mathrm{N}$ linkages in Schiff base, $\mathrm{Ni}$ and $\mathrm{Cu}$ complexes respectively. Absorption bands at $1435.4 \mathrm{~cm}^{-1}$ and $1440 \mathrm{~cm}^{-1}$ show the presence of chelate ring in complexes. The appearance of the M-O bands at $670 \mathrm{~cm}^{-1}$ and $680 \mathrm{~cm}^{-1}$ and M-N bands at $511 \mathrm{~cm}^{-1}$ and $550 \mathrm{~cm}^{-1}$ in both the complexes indicates that AZM-SA is coordinated through $\mathrm{O} \& \mathrm{~N}$ atom. Absorption band appearing at $700 \mathrm{~cm}^{-1}, 706 \mathrm{~cm}^{-1}$ and $709 \mathrm{~cm}^{-1}$ show the presence of $\mathrm{S}$ in the heterocyclic ring. Absorption band at 818 $\mathrm{cm}^{-1}, 815 \mathrm{~cm}^{-1}$ and $838 \mathrm{~cm}^{-1}$ indicate the S-N linkage. The disappearance of phenolic$\mathrm{OH}$ group in complex supports its involvement in complexation. IR spectral data and their tentative assignments are shown in Table 3. 
Table 3. Infrared spectral data $\left(\mathrm{cm}^{-1}\right)$ and their tentative assignments

\begin{tabular}{cccccccc}
\hline Ligand/ Complex & $v(\mathrm{HC}=\mathrm{N})$ & $v\left(\mathrm{SO}_{2} \mathrm{~N}\right)$ & \multicolumn{2}{c}{ Chelate Ring $v \mathrm{M}-\mathrm{N}$} & $v \mathrm{M}-\mathrm{O}$ & $v(\mathrm{Ar}-\mathrm{S})$ & $v(\mathrm{~S}-\mathrm{N})$ \\
\hline AZM-SA & $1680 \mathrm{vs}$ & $1176 \mathrm{vs}$ & - & - & - & $700 \mathrm{~m}$ & $818 \mathrm{~m}$ \\
$(\mathrm{AZM}-\mathrm{SA})_{2} \mathrm{Ni}$ & $1590 \mathrm{~s}$ & $1175 \mathrm{vs}$ & $1435.4 \mathrm{~m}$ & $590 \mathrm{~m}$ & $670 \mathrm{~s}$ & $706 \mathrm{~s}$ & $815 \mathrm{~m}$ \\
$(\mathrm{AZM}-\mathrm{SA})_{2} \mathrm{Cu}$ & $1599 \mathrm{~s}$ & $1173.5 \mathrm{~s}$ & $1440 \mathrm{~m}$ & $550 \mathrm{~s}$ & $680 \mathrm{w}$ & $709 \mathrm{~s}$ & $838 \mathrm{w}$ \\
\hline
\end{tabular}

( $v s=$ very strong, $s=$ strong, $m=$ medium, $w=$ weak).

Hence, on the basis of elemental analysis, IR spectra, electronic spectra, magnetic moment data and conductivity measurement, following structure is proposed for complexes (Figure 2).

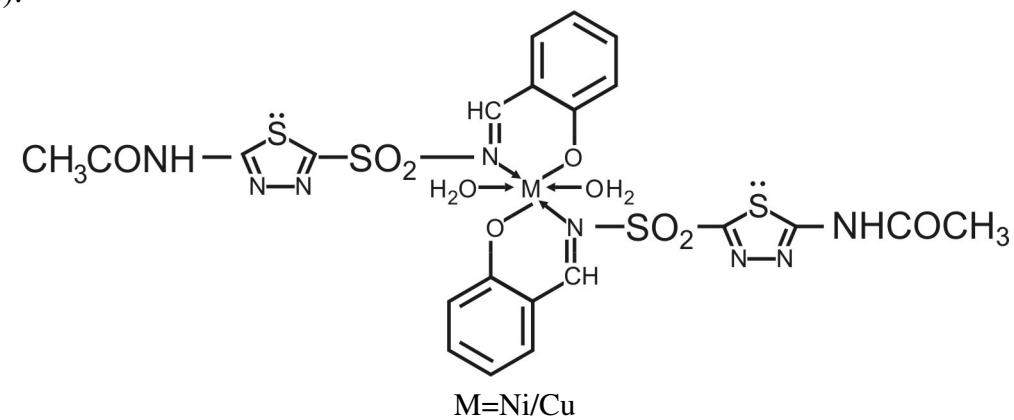

\section{Antibacterial activity}

Figure 2

The zone of inhibition based upon size around the disc was measured. Inhibition zone percentages are recorded in Table 4. From the results it is observed that $\mathrm{Ni(II)}$ and $\mathrm{Cu}$ (II) complexes show greater activity against Escherichia coli as compared to the Schiff base. This indicates that chelation increases the antibacterial activity ${ }^{13}$.

Table 4. Antibacterial activity of Schiff base and complexes

\begin{tabular}{ccc}
\hline Compounds & \multicolumn{2}{c}{$\begin{array}{c}\text { \% of inhibition zone } \\
\text { Escherichia coli } \\
\text { Concentration in ppm } \\
\end{array}$} \\
500 & 1000 \\
\hline $\mathrm{AZM}-\mathrm{SA}$ & - & 40 \\
$(\mathrm{AZM})_{2} \mathrm{Ni}$ & 86 & 92 \\
$(\mathrm{AZM})_{2} \mathrm{Cu}$ & 56 & 87 \\
\hline
\end{tabular}

\section{Acknowledgments}

Authors thank the Principal of Sadhu Vaswani College for providing all laboratory facilities. The authors also owe their sincere thanks to UGC for sanctioning UGC Research Award to Dr. Suman Malik. one of the co-authors. Authors are also indebted to CDRI, Lucknow for providing the facilities of elemental analysis and Dr .V. W. Bhagwat of Vikram University Ujjain for recording IR spectra.

\section{References}

1 Chouhan H Z and Supuran T, Inorg Chim Acta., 2004, 357(11), 3407-3412.

2 Orita Y, Ando A and Urakabe S, Acta Chem Scand., 1997, 51(11), 1078-1084.

3 Baukaiba N, Am J Clin Nutr., 1993, 57, 566-572.

4 Pandley S P, Bhattacharya S K and Sundar S, Indian J Med Res., 1985, 8, 618-620. 
5 Sigel A and Sigel H, Metal Ions in Biological System, Vol. 1-34, Marcel Dekker INC: New York, 1997.

6 Job P, Ann Chim., 1936, 11, 97.

$7 \quad$ Turner S E and Anderson R C, J Amer Chem Soc., 1949, 71, 912-914.

8 Rai B K and Kumar Mukesh, J Indian Council of Chemsist, 2003, 20, 22.

9 Figgis B N, Introduction to Ligand Fields, Wiley Eastern Ltd: New Delhi, 1976, 279.

10 Lane L W and Taylor L T, J Coord Chem., 1973, 2, 295.

11. Rao C N R, Chemical Application of IR Spectroscopy; Academic press: New York, 1963.

12. Nakamoto K, IR Spectra of Inorganic and Co-ordination Compounds; John Wiley: New York, 1956.

13. Kumar V and Dhakarey R, J Indian Chem Soc., 2003, 20(1), 46. 


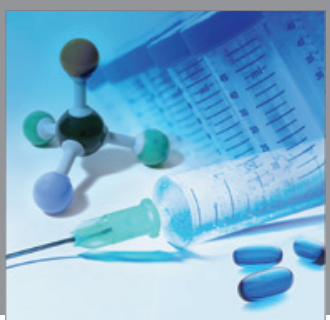

International Journal of

Medicinal Chemistry

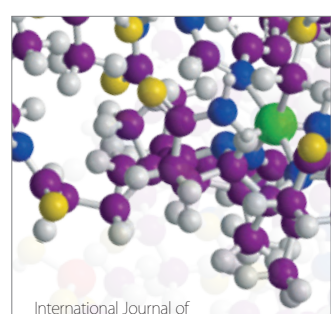

Carbohydrate Chemistry

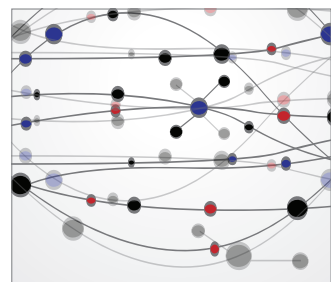

The Scientific World Journal
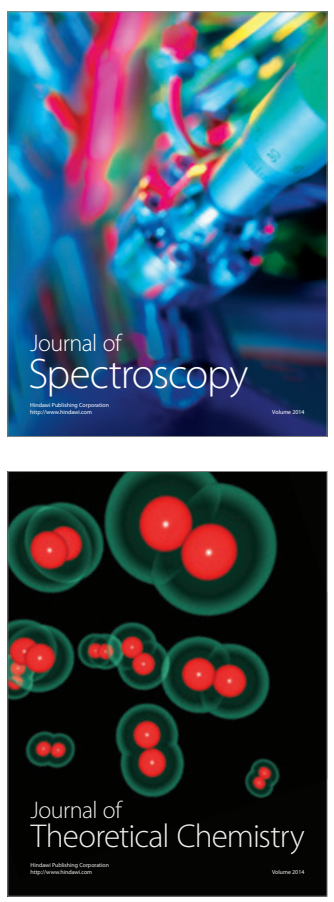
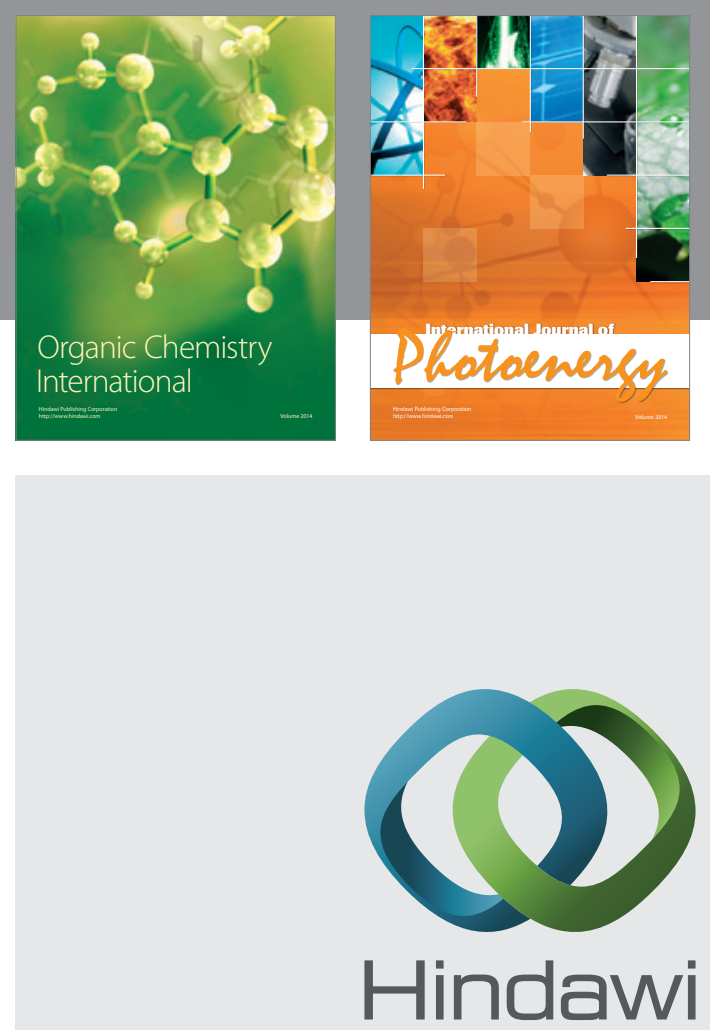

Submit your manuscripts at

http://www.hindawi.com
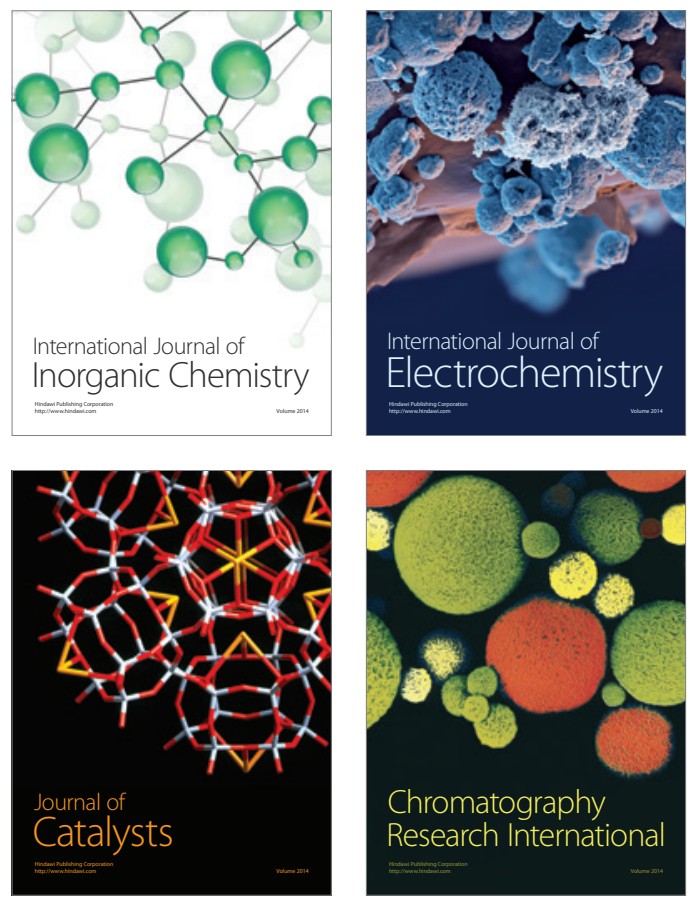
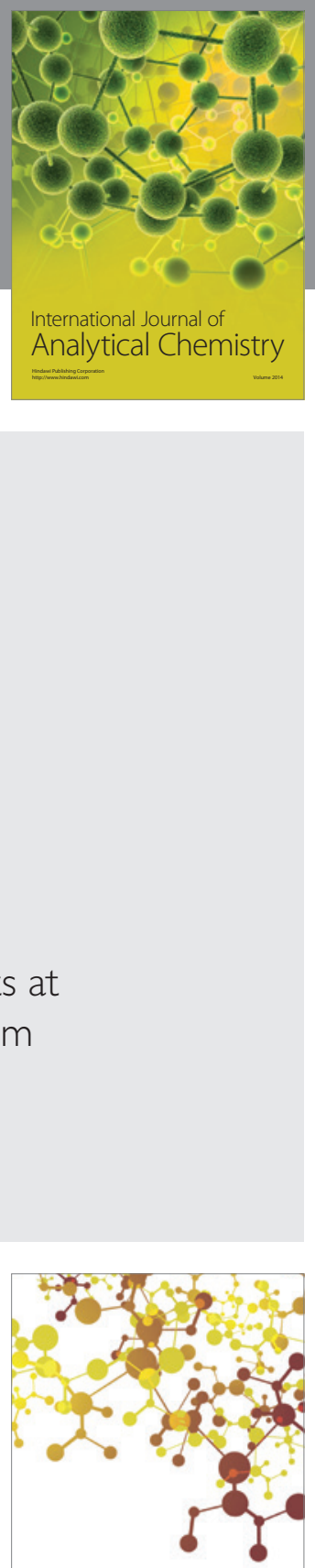

Journal of

Applied Chemistry
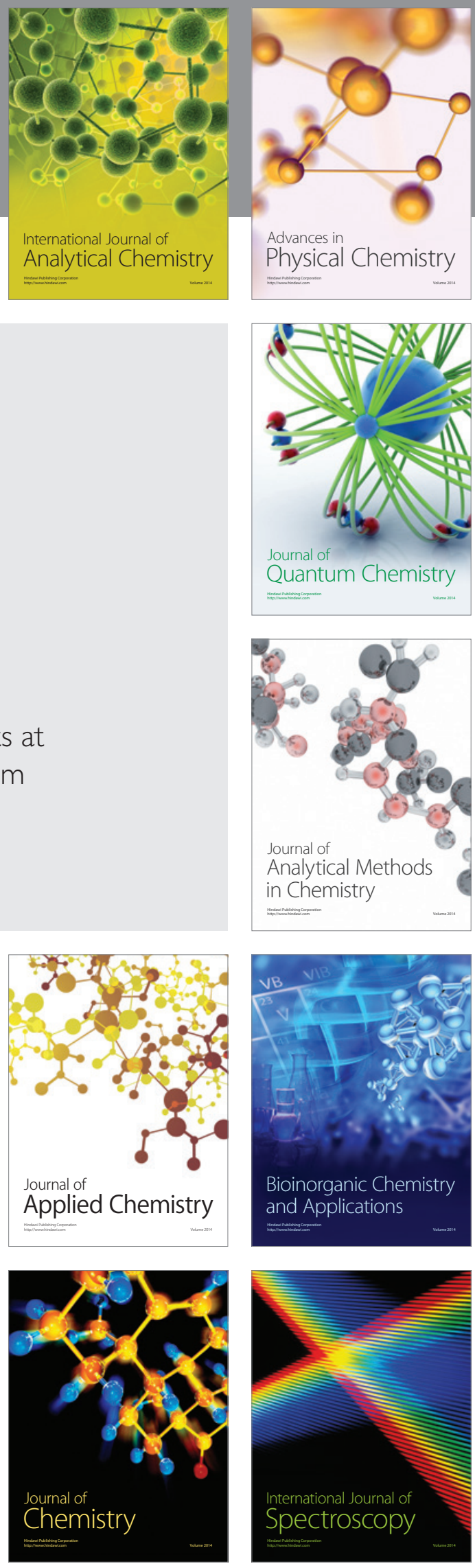